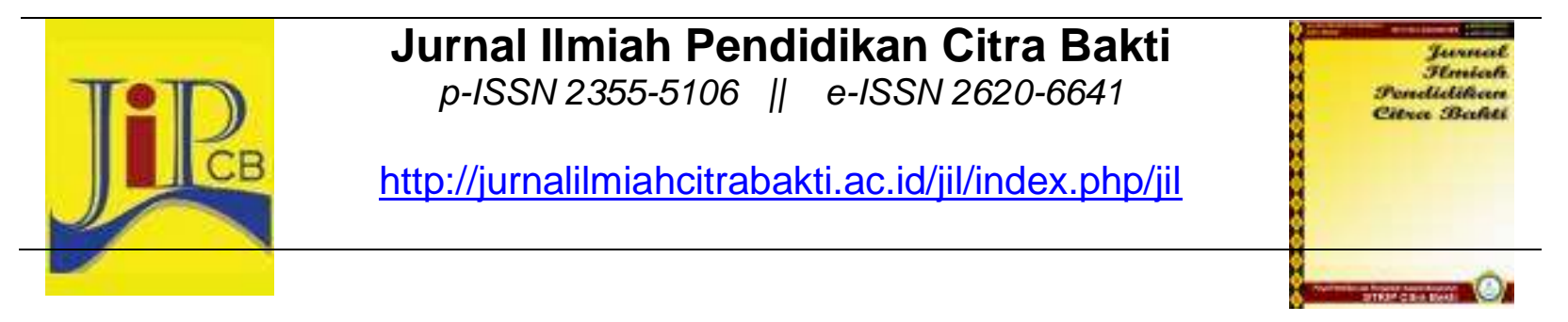

\title{
STRATEGI PENDAMPINGAN UNTUK MENINGKATKAN KINERJA GURU DALAM PEMBELAJARAN MELALUI KEGIATAN SUPERVISI AKADEMIK
}

\author{
Ni Komang Maharwati \\ TK Negeri Negara \\ komangmahawati@gmail.com
}

\section{Histori artikel}

Received:

10 Oktober 2020

Accepted:

29 Oktober 2020

Published:

1 November 2020

\begin{abstract}
Abstrak
Penelitian ini dilakukan untuk meningkatkan kinerja guru dalam pembelajaran melalui kegiatan supervisi akademik untuk guru guru TK. Penelitian ini dilakukan pada TK Negeri Negara Semester I Tahun Pelajaran 2019/2020 yang melibatkan 6 orang guru TK Negeri Negara. Rancangan penelitian dalam dua siklus yang masing-masing terdiri dari perencanaan, pelaksanaan, penilaian dan tindak lanjut analisis yang digunakan adalah teknik deskriptif kuantitatif. Hasil yang diperoleh dari siklus I Perencanaan 71,98 \%,Pelaksanaan 72,44\%, Penilaian 81,3\%, Tindak Lanjut 59,78 \%. Hasil yang diperoleh dari siklus II yaitu perencanaan $92,44 \%$, pelaksanaan $93,81 \%$, penilaian $90,56 \%$ dan tindak lanjut $83 \%$. Dari hasil penelitian dapat disimpulkan bahwa melalui supervisi akademik dan pendampingan yang dilakukan dapat meningkatkan kinerja guru TK.
\end{abstract}

Kata kata kunci: kinerja guru, supervisi akademik, pendampingan guru 
Abstract. This is a classroom action research to improve teachers' instructional performance through Academic Supervision Activities in TK Negeri Negara (Public Kindergarten) in semester I in academic year 2019/2020. A total of six kindergarten teachers are selected as the subjects. This study is conducted in two cycles where each of them covers planning, implementing, evaluating, and reflecting for further follow up analysis. The data will be presented descriptive quantitatively. The study results in the cycle I shows the activeness for supervision as follows; planning $72.98 \%$, implementing $72 \%$, evaluating $82.3 \%$; and reflecting $59.78 \%$. The cycle II reflects an improvement where planning has $92.44 \%$, implementing $93.81 \%$, evaluating $90.56 \%$, and reflecting $83 \%$. This means academic supervision activities and assistance by the principal of the kindergarten has successfully improved teachers performance.

Keywords: teacher performance, academic supervision, teacher assistance

\section{Latar Belakang}

Di dalam dunia pendidikan keberhasilan peserta didik sangat dipengaruhi oleh cara guru dalam mendidik dan memberikan pemahaman yang baik dan benar. Sehingga guru dituntut untuk selalu dalam keadaan yang baik dan optimal dalam menjalankan tugastugasnya, baik dalam mengajar, melakukan tugas administrasi pembelajaran dan lain-lain. Pendidikan yang berkualitas tentunya sangat dipengaruhi oleh guru yang mempunyai kompetenssi yang baik dibidangnya. Oleh sebab itu, peningkatan kualitas guru semakin bertambah untuk membentuk etos kerja yang baik dan juga metode dalam mendidik yang lebih efektif dan efisien (Nurutami, 2016).

Peningkatan kinerja guru merupaakan cerminan dari kualitas guru. Mencetak guru yang mempunyai kualitas yang baik serta mempunya kinerja yang baik pula merupakan suatu hal yang tidak mudah untuk dilaksanakan. Adapun komponen-komponen yang harus diperhatikan untuk meningkatkan kinerja guru adalah perencanaan, pelaksanaan, pelatihan, evaluasi dan supervisi. Kemudian profesionalisme guru meliputi kemampuan: menguasai bahan ajar yang baik, mengelola kegiatan belajar mengajar dengan efektif dan efisien, mengelola kelas dengan baik, mengelola media yang mudah dimengerti dan dipahami oleh peserta didik, memahami landasan kependidikan yang baik, menguasai dan dapat mengendalikan interaksi belajar mengajar yang kondusif, dapat menilai prestasi siswa secara objektif, memahami fungsi dan program layanan bimbingan serta penyuluhan yang berkaitan dengan kepentingan anak sekolah, dan mengenal administrasi sekolah (Pristiawaty, 2016). Selain itu kompetensi lainnya seperti pedagogik, kepribadian, profesional dan sosial harus diperhatikan untuk menjadi guru yang ideal di dalam dunia pendidiakan (Balqis, 2014).

Namun kenyataan yang terjadi dilapangan, kualitas dan kompetensi guru yang ada di Indonesia belum mencapai target yang diinginkan. Berdasarkan data Kemendikbud yaitu dari jumlah keseluruhan 3.015.315 guru di Indonesia, sebanyak 2.294.191 guru berstatus PNS dan guru tetap yayasan (GTY), sedangkan 721.124 guru berstatus guru tidak tetap (GTT) dan tidak mempunyai sertifikasi guru. Kebanyakan guru tersebut masih bermasalah baik 
dalam aspek profesionalisme dan juga kepribadian (Rohman, 2016). Sehingga dengan data seperti itu, maka kualitas dan kopetensi guru masih jauh dari target serta harapan pendidikan di Indonesia.

Pembelajaran yang baik dapat terjadi apabila terjadi interaksi yang baik antara guru, peserta didik serta sarana dan prasarana yang terdapat pada sekolah tersebut (Sahertian, 2008). Faktor yang paling penting dalam terjadinya pembelajaran yang baik adalah guru, sehingga untuk meningkatkan mutu pendidikan di sekolah maka guru harus mendapatkan supervisi yang dilaksanakan secara profesional. Supervisi ini diharapkan mampu membimbing guru dalam memperbaiki cara mengajar dan mampu menggerakan dalam meningkatkan mutu pendidikan di sekolah. Tugas utama guru sebagai pendidik yang profesional adalah mendidik peserta didik dengan baik sekaligus mendidik, membimbing, mengarahkan, menilai serta mengevaluasi peserta didik. Profresionalisme, pengetahuan terhadap materi, sikap dan keterampilan diharapkan harus terus berkembang sehingga guru menjadi salah satu sumber belajar yang mempunyai kompetensi yang baik sesuai dengan perkembangan jaman dan perkembangan IPTEK di Indonesia. Adapun tiga standar kompetensi yang dimaksud adalah (1) kompetensi pengelolaan pembelajaran dan wawasan pendidikan, (2) Kompetensi akademik/vokasional sesuai materi pembelajaran, (3) pengembangan profesi.

Dalam rangka mewujudkan kompetensi tersebut maka guru harus diberikan pembinaan melalui workshop, PKG, KKG, diskusi dan supervisi akademik. Kegiatankegiatan ini harus dilakukan secara periodik sehingga dapat meningkatkan kinerja dan juga sekaligus wawasan guru dalam dunia pendidikan. Berdasarkan hasil observasi dan juga wawancara yang dilakukan di TK Negeri Negara ditemukan beberapa kendala yang dapat menghambat terwujudnya kompetensi guru yang baik. Adapun temuan yang didapatkan adalah (1) guru mempunyai motivasi yang rendah dalam mempelajari hal-hal baru, (2) kesempatan memperoleh pelatihan masih rendah, baik itu secara regional maupun nasional, (3) PKG dan KKG yang kurang efektif, (4) Supervisi lebih banyak berfokus pada sisi administrasi. Pemberian pendidikan lanjutan bagi guru juga merupakan alternatif bagi pembinaan profesi guru di masa yang akan datang. Pendidikan lanjut bagi guru dapat dilakukan dengan memberikan tugas belajar, sehingga menghasilkan guru pembina yang dapat mengimbas guru lainnya untuk mengembangkan profesi (Bustami, 2014).

Kinerja guru dalam mengajar dapat ditingkatkan dengan melakukan pembinaan dan juga supervisi, agar dapat bersaing dengan perkembangan IPTEK yang semakin hari semakin pesat perkembangannya. Pemerintah, kepala sekolah dan juga guru mempunyai tanggung jawab yang besar untuk mencapai tujuan tersebut. Pemerintah telah mengupayakan berbagai macam kegiatan untuk meningkatkan kompetensi guru yaitu 
dengan memberikan pendidikan yang lebih tinggi, guru wajib $\mathrm{S} 1$, pelatihan dan juga tunjangan sertifikasi (Lailatussaadah, 2015).

Sedangkan kepala sekolah bertugas untuk melakukan supervisi, dimana kompetensi kepala sekolah dalam memberikan supervisi meliputi pengetahuan tentang supervisi, menjalin hubungan yang baik dan kemampuan teknis dalam supervisi. Ketiganya merupakan faktor yang sangat penting dimiliki kepala sekolah dalam melakukan supervisi (Sepriadi dan Syarwani Ahmad, 2017). Sehingga untuk memperbaiki kinerja dan wawasan guru dalam pembelajaran di TK Negeri Negara, maka peneliti melakukan penelitian dengan tema strategi pendampingan untuk meningkatkan kinerja guru dalam pembelajaran melalui kegiatan supervisi.

\section{Metode Penelitian}

Metode yang dilakukan peneliti dalam penelitian ini adalah penelitian tindakan, lebih khususnya yaitu penelitian tindakan kelas. Adapun yang menjadi subjek dalam penelitian ini adalah guru TK Negeri Negara, Kelurahan Lelateng, Kecamatan Negara, Kabupaten Jembrana sebanyak 6 orang guru. Penelitian dilakukan, siklus I dilaksanakan selama 2 bulan yaitu pertengahan bulan Juli sampai dengan pertengahan bulan September 2019 . Siklus II dilaksanakan pertengahan bulan September sampai dengan pertengahan bulan Nopember 2019. Prosedur Pelaksanaan tindakan digambarkan Hopkins dan Mc Tagaart menggambarkan alur/siklus PTS sebagai berikut.

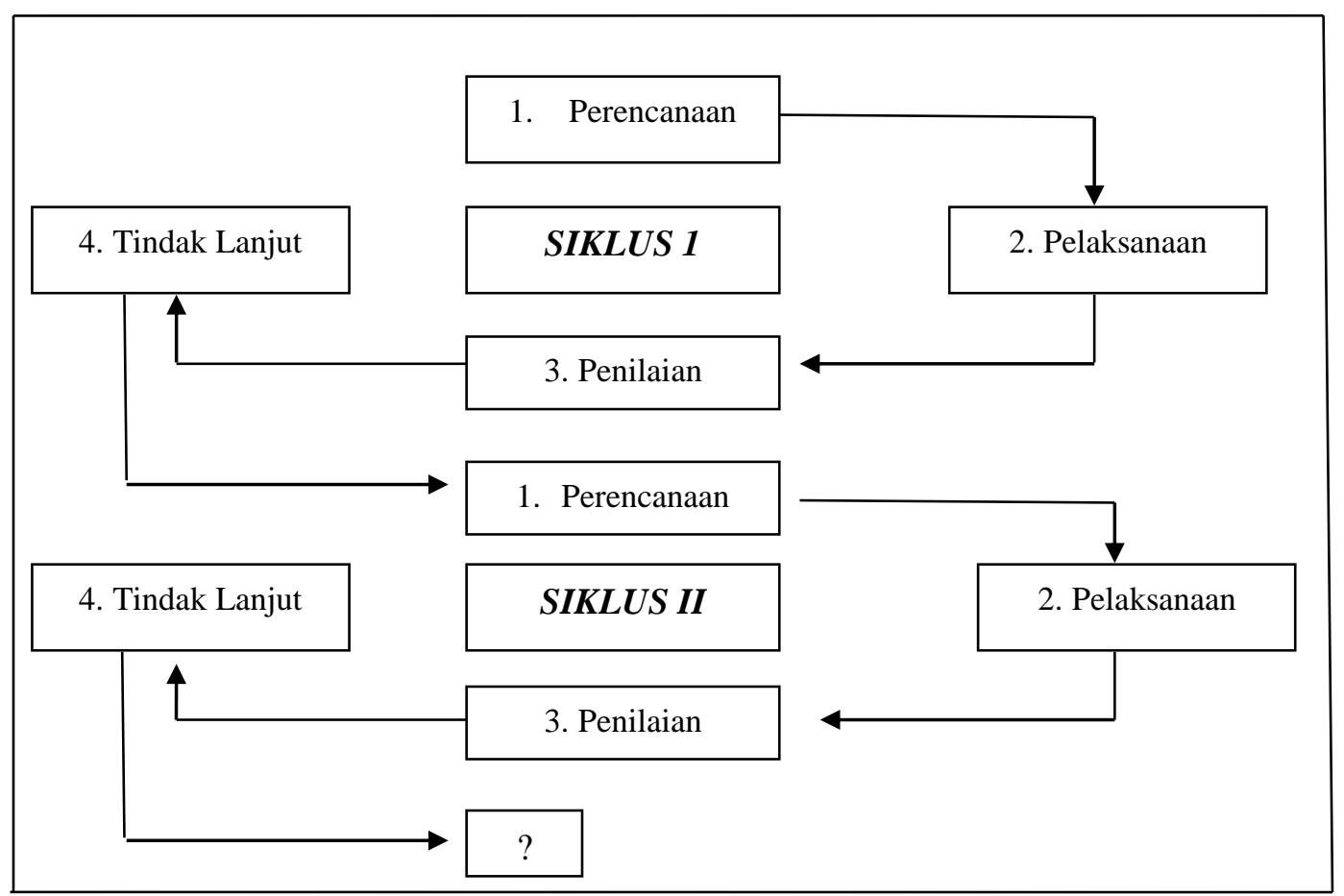

Gambar 1. Diagram Alur/Siklus PTS 
Diagram tersebut menjelaskan alur Penelitian Tindakan Sekolah yang berulang dan berkelanjutan membentuk spiral.

\section{Hasil dan Pembahasan}

\section{Hasil}

Dari hasil penelitian yang diperolah, perencanaan yang dilakukan oleh guru sudah cukup baik tetapi jika diukur dengen indikator yang ditetapkan masih ada beberapa kekuarangan. Adapun hasil penelitiaan perencanaan pada siklus I dapat dilihat pada Tabel I di bawah ini.

Tabel 1. Hasil Penentuan Perencanaan Siklus I

\begin{tabular}{|c|c|c|c|c|}
\hline No & Indikator & $\begin{array}{c}\text { Jumlah } \\
\text { Guru }\end{array}$ & $\begin{array}{l}\text { Jumlah Guru } \\
\text { Berhasil }\end{array}$ & $\begin{array}{l}\text { Persentase } \\
\text { Keberhasilan }\end{array}$ \\
\hline 1 & Mendeskripsikan tujuan pembelajaran & 6 & 5 & 83 \\
\hline 2 & Menentukan materi sesuai dengan kompetensi & 6 & 5 & 83 \\
\hline 3 & $\begin{array}{l}\text { Mengorganisasikan materi berdasarkan urutan } \\
\text { atau kelompok }\end{array}$ & 6 & 4 & 66,4 \\
\hline 4 & Mengalokasikan waktu pembelajaran & 6 & 6 & 100 \\
\hline 5 & Menentukan metode pembelajaran & 6 & 3 & 49,8 \\
\hline 6 & Merancang prosedur pembelajaran & 6 & 4 & 66,4 \\
\hline 7 & Menentukan media pembelajaran & 6 & 4 & 66,4 \\
\hline 8 & $\begin{array}{l}\text { Menentukan sumber belajar yang sesuai } \\
\text { (berupa buku) }\end{array}$ & 6 & 5 & 83 \\
\hline 9 & Menentukan teknik penilaian yang sesuai & 6 & 3 & 49,8 \\
\hline & Rata - Rata Keberhasilan & & $71,98 \%$ & \\
\hline
\end{tabular}

Pada siklus I, hasil penentuan perencanaan mendapatkan skor rata-rata $71,98 \%$. Indikator ketercapaian masih rendah pada menentukan metode pembelajaran dan juga menentukan teknik penilaian yang sesuai. Sedangkan hasil pelaksanaan pembelajaran guru dapat dilihat pada Tabel 2 berikut.

Tabel 2. Hasil Melaksanakan Pembelajaran Tindakan Siklus I

\begin{tabular}{|c|c|c|c|c|}
\hline No & Indikator & $\begin{array}{c}\text { Jumlah } \\
\text { Guru }\end{array}$ & $\begin{array}{l}\text { Jumlah Guru } \\
\text { Berhasil }\end{array}$ & $\begin{array}{c}\text { Persentase } \\
\text { Keberhasilan }\end{array}$ \\
\hline 1 & $\begin{array}{l}\text { Kemampuan membuka pelajaran dengan } \\
\text { metode yang tepat }\end{array}$ & 6 & 5 & 83 \\
\hline 2 & $\begin{array}{l}\text { Menyajikan materi pelajaran secara } \\
\text { sistematis }\end{array}$ & 6 & 4 & 66,4 \\
\hline 3 & $\begin{array}{l}\text { Menerapkan metode dan prosedur } \\
\text { pembelajaran yang telah ditentukan }\end{array}$ & 6 & 4 & 66,4 \\
\hline 4 & Mengatur kegiatan siswa di kelas & 6 & 5 & 83 \\
\hline 5 & Menentukan media pembelajaran & 6 & 4 & 66,4 \\
\hline 6 & Menggunakan sumber belajar & 6 & 4 & 66,4 \\
\hline 7 & $\begin{array}{l}\text { Memotivasi siswa dengan berbagai cara yang } \\
\text { positif }\end{array}$ & 6 & 5 & 83 \\
\hline 8 & $\begin{array}{l}\text { Melakukan interaksi dengan siswa } \\
\text { menggunakan bahasa yang komunikatif }\end{array}$ & 6 & 5 & 83 \\
\hline 9 & Memberikan pertanyaan dan umpan balik & 6 & 4 & 66,4 \\
\hline 10 & Menyimpulkan pembelajaran & 6 & 4 & 66,4 \\
\hline
\end{tabular}




\begin{tabular}{cllll}
\hline 11 & Menggunakan waktu secara efektif & 6 & 4 & 66,4 \\
\hline Rata - Rata Keberhasilan & & $72,44 \%$ & \\
\hline
\end{tabular}

Pada siklus I, hasil melaksanakan pembelajaran mendapatkan skor rata-rata $72,44 \%$. Hasil keberhasilan melaksanakan pembelajaran rendah, hal ini terjadi karena guru belum memaksimalkan beberapa indikator dalam pelaksanaan pembelajaran. Selanjutnya data hasil menilai prestasi belajar siswa dapat dilihat pada Tabel 3 di bawah ini.

Tabel 3. Hasil Menilai Prestasi Belajar Siklus I

\begin{tabular}{clccc}
\hline No. & \multicolumn{1}{c}{ Indikator } & $\begin{array}{c}\text { Jumlah } \\
\text { Guru }\end{array}$ & $\begin{array}{c}\text { Jumlah Guru } \\
\text { Berhasil }\end{array}$ & $\begin{array}{c}\text { Persentase } \\
\text { Keberhasilan }\end{array}$ \\
\hline 1 & Menyusun perangkat penilaian & 6 & 5 & 83 \\
2 & Melaksanakan penilaian & 6 & 5 & 83 \\
3 & Memeriksa jawaban/memberi skor & 6 & 4 & 66,4 \\
4 & Menilai hasil belajar & 6 & 6 & 100 \\
5 & Mengolah hasil belajar & 6 & 4 & 66,4 \\
6 & Menganalisis hasil belajar & 6 & 4 & 66,4 \\
7 & Menyimpulkan hasil belajar & 6 & 4 & 66,4 \\
8 & Menyusun laporan hasil belajar & 6 & 6 & 100 \\
9 & Memperbaiki perangkat penilaian & 6 & 6 & 100 \\
\hline & Rata - Rata Keberhasilan & \multicolumn{3}{c}{$81,3 \%$} \\
\hline
\end{tabular}

Pada siklus I, hasil menilai prestasi belajar siswa mendapatkan nilai rata-rata $81,30 \%$. Hasil menilai siswa masih kurang pada beberapa aspek indikator yang ingin dicapai. Sehingga perlu dilakukan perbaikan pada siklus berikutnya. Selanjutnya dilakukan kegiatan tindak lanjut hasil penilaian. Adapun data yang diperoleh pada bagian tindaklanjut dilihat pada Tabel 4

Tabel 4. Hasil Melaksanakan Tindak Lanjut Hasil Penilaian Siklus I

\begin{tabular}{|c|c|c|c|c|}
\hline No. & Indikator & $\begin{array}{c}\text { Jumlah } \\
\text { Guru }\end{array}$ & $\begin{array}{c}\text { Jumlah Guru } \\
\text { Berhasil }\end{array}$ & $\begin{array}{l}\text { Persentase } \\
\text { Keberhasilan }\end{array}$ \\
\hline 1 & $\begin{array}{l}\text { Mengidentifikasi kebutuhan tindak lanjut } \\
\text { hasil penilaian }\end{array}$ & 6 & 4 & 66,4 \\
\hline 2 & Menyusun program tindak lanjut & 6 & 5 & 83 \\
\hline 3 & Melaksanakan tindak lanjut & 6 & 3 & 49,8 \\
\hline 4 & $\begin{array}{l}\text { Mengevaluasi hasil tindak lanjut hasil } \\
\text { penilaian }\end{array}$ & 6 & 3 & 49,8 \\
\hline \multirow[t]{2}{*}{5} & $\begin{array}{l}\text { Menganalisis hasil evaluasi program tindak } \\
\text { lanjut hasil penilaian }\end{array}$ & 6 & 3 & 49,8 \\
\hline & Rata-rata Keberhasilan & & $59,76 \%$ & \\
\hline
\end{tabular}

Pada siklus I, tindak lanjut hasil penilaian mendapatkan nilai rata-rata 59,76\%. Nilai ini tergolong rendah sehinga perlu dilakukan perbaikan pada siklus berikutnya. Berikut ini akan ditampilkan grafik keberhasilan siklus I yang dapat dilihat pada Gambar 2. 


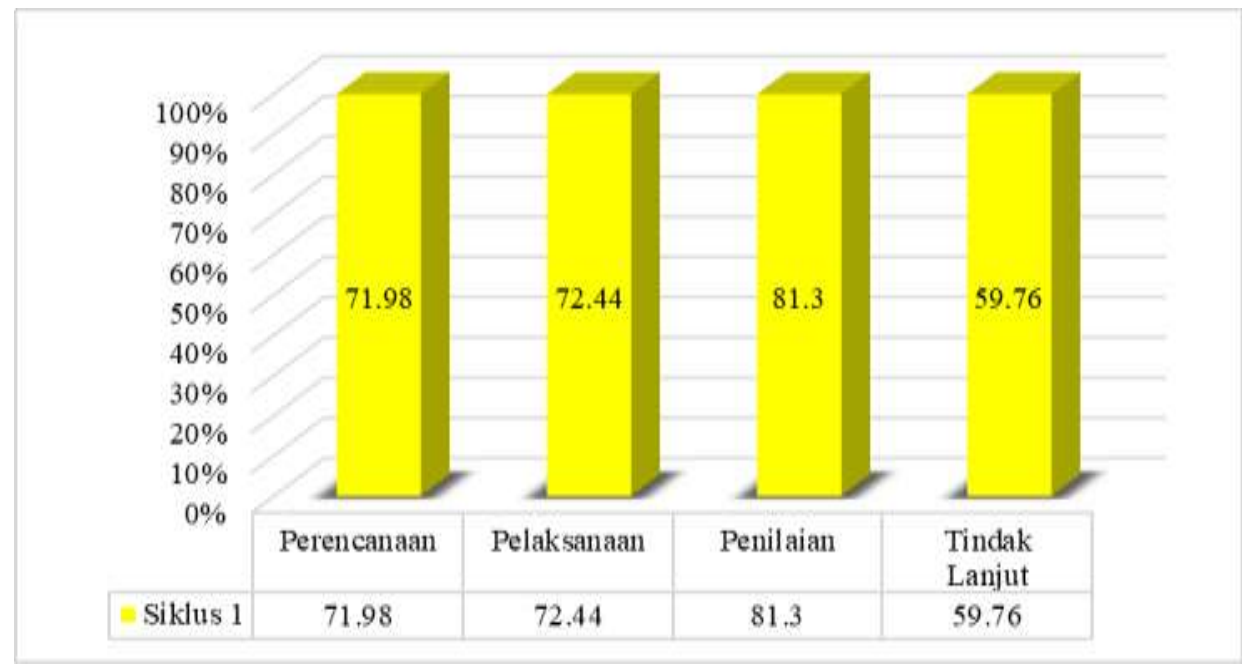

Gambar 2. Grafik Keberhasilan Siklus I

Pada Gambar 2. Terlihat bahwa hasil perencanaan, pelaksanaan, penilaian dan tindak lanjut masih rendah sehingga perlu dilakukan perbaikan pada siklus II. Dasar dari perbaikan yang dilakukan pada siklus II dilakukan setelah melihat hasil dari siklus I. Aspekaspek yang sudah baik pada siklus I dipertahankan sedangkan aspek yang mendapatkan presentase kurang diperbaiki dengan harapan akan meningkat pada siklus II. Adapun hasil perencanaan pada siklus II dapat dilihat pada Tabel 5 di bawah ini.

Tabel 5. Hasil Penentuan Perencanaan Siklus II

\begin{tabular}{|c|c|c|c|c|}
\hline No. & Indikator & $\begin{array}{c}\text { Jumlah } \\
\text { Guru }\end{array}$ & $\begin{array}{l}\text { Jumlah } \\
\text { Guru } \\
\text { Berhasil }\end{array}$ & $\begin{array}{l}\text { Persentase } \\
\text { Keberhasilan }\end{array}$ \\
\hline 1 & Mendeskripsikan Tujuan Pembelajaran & 6 & 6 & 100 \\
\hline 2 & Menentukan materi sesuai dengan kompetensi & 6 & 6 & 100 \\
\hline 3 & $\begin{array}{l}\text { Mengorganisasikan materi berdasarkan urutan } \\
\text { atau kelompok }\end{array}$ & 6 & 5 & 83 \\
\hline 4 & Mengalokasikan waktu & 6 & 6 & 100 \\
\hline 5 & Menentukan metode pembelajaran & 6 & 5 & 83 \\
\hline 6 & Merancang prosedur pembelajaran & 6 & 5 & 83 \\
\hline 7 & Menentukan media pembelajaran & 6 & 5 & 83 \\
\hline 8 & $\begin{array}{l}\text { Menentukan sumber belajar yang sesuai } \\
\text { (berupa buku, modul, program komputer dan } \\
\text { sejenisnya) }\end{array}$ & 6 & 6 & 100 \\
\hline 9 & Menentukan teknik penilaian yang sesuai & 6 & 6 & 100 \\
\hline & Rata - Rata Keberhasilan & \multicolumn{3}{|c|}{$92,44 \%$} \\
\hline
\end{tabular}

Hasil yang diperoleh pada siklus II menunjukkan peningkatan nilai perencanaan pembelajaran dengan nilai rata-rata 92,44\%. Hal ini menunjukkan bahwa refleksi dan perbaikan yang dilakukan pada siklus II berjalan dengan baik. Selanjutnya gambaran guru TK Negeri Negara dalam melaksanakan proses belajar mengajar berdasarkan indikator yang sudah ditentukan dapat dilihat pada Tabel 6 berikut ini. 
Tabel 6. Hasil Melaksanakan Pembelajaran Tindakan Siklus II

\begin{tabular}{|c|c|c|c|c|}
\hline No. & Indikator & $\begin{array}{l}\text { Jumlah } \\
\text { Guru }\end{array}$ & $\begin{array}{l}\text { Jumlah Guru } \\
\text { Berhasil }\end{array}$ & $\begin{array}{l}\text { Persentase } \\
\text { Keberhasilan }\end{array}$ \\
\hline 1 & Membuka pelajaran dengan metode yang tepat & 6 & 6 & 100 \\
\hline 2 & Menyajikan materi pelajaran secara sistematis & 6 & 5 & 83 \\
\hline 3 & $\begin{array}{l}\text { Menerapkan metode dan prosedur pembelajaran } \\
\text { yang telah ditentukan }\end{array}$ & 6 & 5 & 83 \\
\hline $\begin{array}{l}4 \\
5 \\
6 \\
7\end{array}$ & $\begin{array}{l}\text { Mengatur kegiatan siswa di kelas } \\
\text { Menentukan media pembelajaran } \\
\text { Menggunakan sumber belajar } \\
\text { Memotivasi siswa dengan berbagai cara yang }\end{array}$ & $\begin{array}{l}6 \\
6 \\
6 \\
6\end{array}$ & $\begin{array}{l}6 \\
5 \\
6 \\
6\end{array}$ & $\begin{array}{c}100 \\
83 \\
100 \\
100\end{array}$ \\
\hline 8 & $\begin{array}{l}\text { positif } \\
\text { Melakukan interaksi dengan siswa } \\
\text { menggunakan bahasa yang komunikatif }\end{array}$ & 6 & 6 & 100 \\
\hline $\begin{array}{c}9 \\
10 \\
11\end{array}$ & $\begin{array}{l}\text { Memberikan pertanyaan dan umpan balik } \\
\text { Menyimpulkan pembelajaran } \\
\text { Menggunakan waktu secara efektif }\end{array}$ & $\begin{array}{l}6 \\
6 \\
6\end{array}$ & $\begin{array}{l}5 \\
6 \\
6\end{array}$ & $\begin{array}{l}83 \\
100 \\
100\end{array}$ \\
\hline & Rata - Rata Keberhasilan & & $93,81 \%$ & \\
\hline
\end{tabular}

Hasil yang diperoleh pada siklus II terjadi peningkatan nilai pelaksanaan pembelajaran dengan nilai rata-rata $93,81 \%$. Hal ini mengindikasikan bahwa perbaikan yang dilakukan pada siklus II bekerja secara efektif. Selanjutnya data tentang penilaian prestasu belajar siswa dapat dilihat pada Tabel 7 di bawah ini.

Tabel 7. Hasil Menilai Prestasi Belajar Siklus II

\begin{tabular}{|c|c|c|c|c|}
\hline No. & Indikator & $\begin{array}{c}\text { Jumlah } \\
\text { Guru }\end{array}$ & $\begin{array}{l}\text { Jumlah Guru } \\
\text { Berhasil }\end{array}$ & $\begin{array}{c}\text { Persentase } \\
\text { Keberhasilan }\end{array}$ \\
\hline 1 & $\begin{array}{l}\text { Menyusun soal/perangkat } \\
\text { penilaian }\end{array}$ & 6 & 5 & 83 \\
\hline 2 & Melaksanakan penilaian & 6 & 5 & 83 \\
\hline 3 & $\begin{array}{l}\text { Memeriksa jawaban/memberi } \\
\text { skor }\end{array}$ & 6 & 5 & 83 \\
\hline 4 & Menilai hasil belajar & 6 & 6 & 100 \\
\hline 5 & Mengolah hasil belajar & 6 & 6 & 100 \\
\hline 6 & Menganalisis hasil belajar & 6 & 5 & 83 \\
\hline 7 & Menyimpulkan hasil belajar & 6 & 5 & 83 \\
\hline 8 & Menyusun laporan hasil belajar & 6 & 6 & 100 \\
\hline 9 & $\begin{array}{l}\text { Memperbaiki soal/perangkat } \\
\text { penilaian }\end{array}$ & 6 & 6 & 100 \\
\hline & Rata - Rata Keberhasilan & \multicolumn{3}{|c|}{$90,56 \%$} \\
\hline
\end{tabular}

Pada siklus II terjadi peningkatan hasil prestasi belajar siswa dengan nilai rata-rata $90,56 \%$. Hasil menilai siswa sudah meningkat pada beberapa aspek indikator yang ingin dicapai. Selanjutnya dilakukan kegiatan tindak lanjut hasil penilaian. Adapun data yang diperoleh pada bagian tindakl anjut dilihat pada Tabel 8 di bawah ini. 
Tabel 8. Hasil Melaksnakan Tindak Lanjut Hasil Penilaian Siklus II

\begin{tabular}{|c|c|c|c|c|}
\hline No. & Indikator & $\begin{array}{c}\text { Jumlah } \\
\text { Guru }\end{array}$ & $\begin{array}{c}\text { Jumlah Guru } \\
\text { Berhasil }\end{array}$ & $\begin{array}{c}\text { Persentase } \\
\text { Keberhasilan }\end{array}$ \\
\hline 1 & $\begin{array}{l}\text { Mengidentifikasi kebutuhan } \\
\text { tindak lanjut hasil penilaian }\end{array}$ & 6 & 5 & 83 \\
\hline 2 & Menyusun program tindak lanjut & 6 & 5 & 83 \\
\hline 3 & Melaksanakan tindak lanjut & 6 & 5 & 83 \\
\hline 4 & $\begin{array}{l}\text { Mengevaluasi hasil tindak lanjut } \\
\text { hasil penilaian }\end{array}$ & 6 & 5 & 83 \\
\hline 5 & $\begin{array}{l}\text { Menganalisis hasil evaluasi } \\
\text { program tindak lanjut hasil } \\
\text { penilaian }\end{array}$ & 6 & 5 & 83 \\
\hline & Rata-rata Keberhasilan & \multicolumn{3}{|c|}{$83,00 \%$} \\
\hline
\end{tabular}

Pada siklus II terjadi peningkatan tindak lanjut hasil penilaian dengan nilai rata-rata $83,00 \%$. Peningkatan nilai pada siklus II mengindikasikan perbaikan yang dilakukan berjalan dengan efektif. Berikut ini akan ditampilkan grafik keberhasilan siklus I yang dapat dilihat pada Gambar 3 di bawah ini.

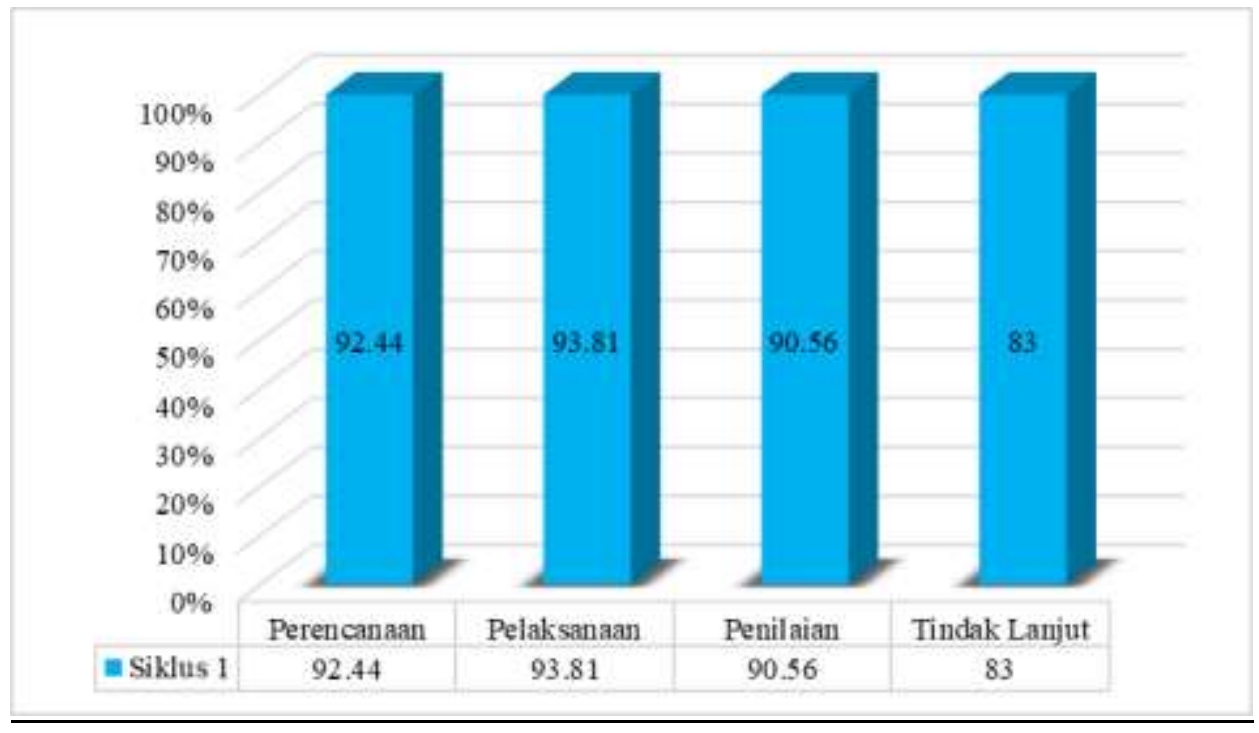

Gambar 3. Grafik Keberhasilan Siklus II

Pada Gambar 3. terlihat bahwa hasil perencanaan, pelaksanaan, penilaian dan tindak lanjut mengalami peningkatan dari siklus I. Untuk data perbandingan, berikut ini akan ditampilkan grafik perbandingan siklus I dan siklus II yang dapat dilihat pada gambar 4 di bawah ini. 


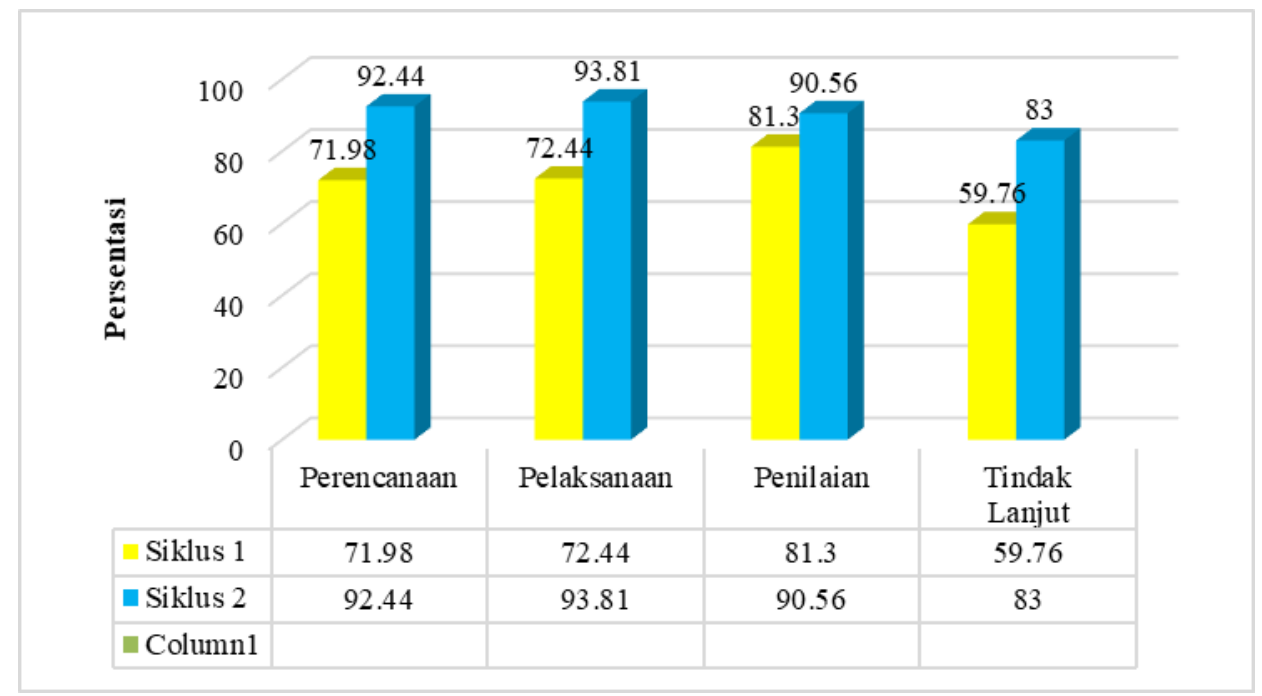

\section{Gambar 4. Grafik Perbandingan Keberhasilan Siklus I dan Siklus II}

Pada gambar 4 terlihat bahwa hasil dari perencanaan, pelaksanaan, penilaian dan tindak lanjut pada siklus I mengalami peningkatan pada silklus II. Hal ini terjadi karena kepala sekolah TK Negeri Negara melakukan bimbingan yang baik dan terstruktur kepada guru TK Negeri Negara. Beberapa temuan ditemukan pada penelitian ini.

\section{Pembahasan}

Hasil dari perencanaan, pelaksanaan, penilaian dan tindak lanjut pada siklus I mengalami peningkatan pada siklus II. Hal ini terjadi karena Kepala Sekolah TK Negeri Negara melakukan supervisi dan bimbingan yang baik serta terstruktur kepada guru-guru di TK Negeri Negara. Jika pelaksanaan supervisi belajar mengajar tinggi maka sikap dan kompetensi mengajar dapat ditingkatkan (Darishah, 2017). Sebaliknya supervisi yang salah akan berdampak negatif terhadap guru itu sendiri karena merasa diawasi dan timbul perasaan tidak nyaman (Pajak, 2001). Untuk menanggulangi hal tersebut maka hubungan supervisior dan juga guru harus akrab dan saling mengenal dengan baik. Supervisi kegiatan belajar mengajar guru di kelas merupakan metode yang paling baik untuk mengevaluasi efektivitas pembelajaran di sekolah (Ebmeier, 2003). Untuk mendukung kegiatan supervisi ini, pembentukan tim konsultan oleh kepala sekolah untuk meningkatkan efektivitas pengajaran juga penting untuk dilakukan (Agih, 2015). Kegiatan ini dilakukan agar semua guru melaksanakan layanan belajar mengajar dengan kualitas terbaik dan profesional (Ahmad Kamal, 2015). Dari hasil supervisi tersebut, ada beberapa temuan-temuan penting yang diperoleh peneliti dalam penelitian yang sudah dilakukan.

Temuan pertama yaitu kinerja guru meningkat dalam membuat perencanaan pembelajaran yaitu dari nilai rata-rata $71,98 \%$ pada siklus I meningkat menjadi $92,44 \%$ pada siklus II. Peningkatan ini terjadi karena adanya kerjasama antar guru kelas dan dibarengi 
dengan bimbingan yang baik dari peneliti. Poin penting dalam meningkatkan kinerja guru dalam hal membuat persiapan pembelajaran adalah: (1) Pemberian jadwal dan format supervisi pada awal semester agar dapat dipelajari dengan baik, (2) Perkembangan perangkat pembelajaran yang dibuat oleh guru TK Negeri Negara harus selalu dipantau oleh peneliti, (3) Peneliti selalu melihat kelebihan dan kekurangan perangkat pembelajaran yang sudah dibuat oleh guru TK Negeri Negara, (4) Memberikan catatan khusus kepada guru TK Negeri Negara, (5) Perangkat pembelajaran yang dibuat oleh guru TK Negeri Negara harus dinilai dengan penuh perhatian, memberikan bimbingan, menerima argumen, sehingga hubungan guru dan peneliti menjadi lebih positif.

Temuan kedua yaitu kinerja guru meningkat dalam melaksanakan pembelajaran. Terlihat dari hasil rata-rata yaitu $72,44 \%$ pada siklus I meningkat menjadi $93,81 \%$ pada siklus II. Peningkatan pelaksanaan pembelajaran dapat dilakukan dengan beberapa cara yaitu: (1) Peneliti berperan sebagai rekan kerja dan bukan sebagai penilai, sehingga guru yang disupervisi menjadi lebih tenang dalam mengajar, (2) Permasalahan di dalam kelas sudah didiskusikan oleh guru dan juga peneliti, sehingga masalah-masalah yang timbul dapat diatasi dengan mudah, (3) Setiap peristiwa yang terjadi dalam pembelajaran dikelas harus dicatat dengan baik dan detail, (4) Modern Learning selalu menjadi acuan peneliti dalam memberikan contoh pembelajaran yang baik di kelas, (5) Peneliti selalu memberikan contoh yang baik dalam menjelaskan tujuan, penyajian materi, pemberian umpan balik kepada guru yang mengalami kesulitan dalam hal tersebut, (6) Peneliti selalu melihat dan mengobservasi guru dalam proses pembelajaran

Temuan ketiga pada penelitian ini adalah kemampuan kinerja guru meningkat pada aspek menilai prestasi siswa. Hal ini terlihat pada hasil siklus I dengan nilai rata-rata $81,30 \%$ meningkat menjadi 90,56\%. Pada penelitian tindakan yang dilakukan di TK Negeri Negara pelaksanaan supervisi edukatif kolaboratif secara berkesinambungan memberikan perubahan yang baik terhadap guru TK Negeri Negara dalam menyusun soal yang baik, perangkat penilaian yang jelas dan mudah dipahami, memeriksa hasil kerja siswa dengan cepat dan efisien, menilai hasil kerja siswa secara objektif, menganalisis nilai siswa, menyusun laporan dengan baik dan juga memperbaiki soal yang dianggap rancu dan sulit dipahami oleh siswa. Sebelumnya guru banyak menghadapi kendala yang berkaitan dengan pelaksanaan penilaian. Adapun beberapa hal yang harus diperhatikan untuk meningkatkan kinerja guru adalah: (1) Perangkat penilaian selalu didiskusikan oleh guru bersama dengan peneliti, (2) Guru selalu melakukan penilaian sesuai dengan pedoman yang sudah disepakati dengan peneliti, (3) Kriteria penilaian harus jelas dan sesuai dengan penskoran, pembobotan dan pengolahan nilai, (4) Hasil penilaian harus dianalisis dan dilaporkan kepada bagian kurikulum. 
Temuan keempat dalam penelitian ini yaitu peningkatan tindak lanjut hasil penilaian yang sudah dilakukan oleg guru TK Negeri Negara. Hal ini terlihat dari hasil rata-rata pada siklus I yaitu 59,76\% meningkat menjadi $83,00 \%$ pada siklus II. Adapun beberapa hal yang harus diperhatikan untuk meningkatkan kinerja guru adalah: (1) Program tindak lanjut hasil penilaian selalu dibuat bersama-sama oleh guru dan juga peneliti, (2) Contoh yang baik dalam pelaksanaan tindak lanjut dicontohkan oleh peneliti dan selanjutnya guru menerapkannya pada pelaksanaan yang sebenarnya, (3) Program tindak lanjut seperti membuat, melaksanakan dan mengenalisis selalu diawali dengan proses diskusi antara peneliti dan juga guru di TK Negeri Negara. Dan temuan kelima terlihat dari peningkatan kinerja guru dalam aspek menyusun program pembelajaran yang sistematis, melaksanakan pembelajaran yang baik dan dapat memotivasi siswa, menilai prestasi belajar anak dengan objektif serta selalu melaksanakan tindak lanjut hasil prestasi belajar siswa.

\section{Kesimpulan}

Berdasarkan hasil penelitian yang sudah dilakukan, rancangan penelitian dalam dua siklus yang masing-masing terdiri dari Perencanaan, Pelaksanaan, Penilaian dan Tindak Lanjut. Hasil yang diperoleh dari siklus I Perencanaan 71,98 \%,Pelaksanaan 72,44 \%, Penilaian 81,30 \%, Tindak Lanjut 59,78 \%. Pada siklus II terjadi peningkatan nilai rata-rata yaitu Perencanaan 92,44\%, Pelaksanaan 93,81\%, Penilaian 90,56 \% dan Tindak Lanjut $83,00 \%$. Dari hasil Penelitian menunjukkan bahwa melalui supervisi akademik dan pendampingan yang dilakukan oleh Kepala TK Negeri Negara dapat meningkatkan Kinerja Guru TK Negeri Negara.

\section{Daftar Pustaka}

Agih, A.A. (2015). Effective school management and supervision: Imperative for quality education service delivery. African Research Review, Vol. 9 (3), 62-74.

Ahmad Kamal, A., Abd. R.I. \& Zuraidah, A. (2015). Factors affecting the teachers' motivation towards the implementation of teaching supervision in secondary schools. Journal of Advanced Review on Scientific Research, Vol. 12 (1), 1-10.

Bustami. (2014). Strategi Supervisor dalam Meningkatkan Profesionalisme Guru MIN di Kecamatan Daha Utara Kabupaten Hulu Sungai Selatan. Jurnal Kindai. Vol. 10 (2), 126-141.

Darishah, P., Daud, Y., \& Fauzee, M. S. O. (2017). Teaching and learning supervision by school management, attitude of teachers and competency of teaching. International Journal of Development and Sustainability, Vol. 6 (10), 1367-1381

Ebmeier, H. (2003). How supervision influences teacher efficacy and commitment: an investigation of a path model. Journal of Curriculum and Supervision, Vol. 18 (2), 110141. 
Lailatussaadah. (2015). Upaya Peningkatan Kinerja Guru. Jurnal Intelektualita. Vol. 3 (1),1525.

Nurutami, A. R. (2016). Kompetensi Profesional Guru Sebagai Determinan Terhadap Minat Belajar Siswa. Jurnal Pendidikan Manajemen Perkantoran, Vol. 1 (1), 119-127.

Pajak, E. (2001). Clinical supervision and physchological functions: a new direction for theory and practice. Journal of Curriculum and Supervision, Vol. 17 (3), 189-205.

Pristiawaty, E. (2016). Kompetensi Profesional Guru yang Bersertifikat dapat meningkatkan prestasi belajar siswa, Medan.

Putri Balqis. P., Usman. N., \& Ibrahim. S. (2014). Kompetensi Pedagogik Guru Dalam Meningkatkan Motivasi Belajar Siswa Pada SMPN 3 Ingin Jaya Kabupaten Aceh Besar. Jurnal Administrasi Pendidikan, Vol. 2 (1), 25-38.

Rohman, M. (2016). Problematika Guru dan Dosen dalam Sistem Pendidikan Nasional. Jurnal Cendikia, Vol. 14 (1), 49-71.

Sahertian, P. A. (2008). Konsep dasar dan Teknik Supervisi Pendidikan dalam Rangka Pengembangan Sumber Daya Manusia. Jakarta: Rineka Cipta.

Sepriadi., \& Ahmad. S. (2017). Pengaruh Kepala Sekolah sebagai Supervisor Akademik terhadap Kinerja Guru di SMK PGRI Tanjung Raja. Jurnal Manajemen, Kepemimpinan, dan Supervisi Pendidikan, Vol. 2 (1), 55-76. 